\title{
THE GIRL FROM IPANEMA AT RISK: WOMEN'S HEALTH AND THE PHYSICAL ENVIRONMENT
}

Becky L. Jacobs*

AbSTRACT: This essay explores the issue of women's health in Rio de Janeiro, a topic at the intersection of the physical and human environments and one that is inextricably intertwined with the environmental justice and social inclusion concerns. A society often can be defined by its citizens' health indicators and access to health, particularly those of the most vulnerable members of its society, including the poor, women, and children. Health has been included in the panoply of human rights which aspirationally all nations should recognize and promote (Kuszler 2007), and it is a prominent item on the agenda of many international organizations. Today, "[e]nvironmental hazards are responsible for about a quarter of the total burden of disease worldwide . . . As many as 13 million deaths can be prevented every year by making our environments healthier" (WHO 2010). Many of these hazards persist in Rio's socio-physical environment, and, while men, women, and children all are susceptible to environmentally-related health issues, women have particular conditions which are specifically related to their gender (EHSO).

KEYWORDS: Women's health, Environmental health, Socio-physical environment.

\footnotetext{
* Associate Professor of Law, University of Tennessee College of Law. Email: jacobs@utk.edu. The author would like to thank Professor Colin Crawford, o fundador da festa, Professor Maria Clara Dias, Professor Romulo Sampaio, and the institutional and other organizers for the opportunity to participate in Study Space V and its publications.
} 


\section{INTRODUCTION}

It was incredibly difficult to choose a topic on which to write for this publication. Our Study Space V experience presented an abundance of topical riches pertaining to cultural diversity, property rights, and sustainable development in the context of Rio's dramatic growth in recent years. I finally settled upon the issue of women's health, a topic at the intersection of the physical and human environments and one that is inextricably intertwined with the environmental justice concerns on which we focused in Study Space V.

It also is relevant to the purpose of this publication, social inclusion. A society often can be defined by its citizens' health indicators and access to health, particularly those of its most vulnerable citizens, including the poor, women, and children. Health has been included in the panoply of human rights which aspirationally all nations should recognize and promote (Kuszler 2007), and it is a prominent item on the agenda of many international organizations, such as, but not only, the World Health Organization, but also the World Trade Organization and the United Nations. (Abbott 2002). For example, a number of the United Nations Millennium Goals define targets that seek to improve the health of the world's poor by 2015 (MDG 2000). There also are international agreements that address global health, including the International Covenant on Economic, Social and Cultural Rights, which explicitly recognizes "the right of everyone to the enjoyment of the highest attainable standard of physical and mental health" (ICESCR, art. 12, 1966).

That the environment influences health is indisputable (WHO 2010) and is a part of the medical historical record. In his treatise "Airs, Waters, and Places[,]" Hippocrates commented upon the relationship between the environment and human health (Hippocrates 400 B.C.E.). Today, "[e]nvironmental hazards are responsible for about a quarter of the total burden of disease worldwide . . . As many as 13 million deaths can be prevented every year by making our environments healthier" (WHO 2010). An improved environment produces better health outcomes, globally and in Brazil.

Before I explore issues specific to Rio de Janeiro, let's briefly consider the many ways the physical environment can impact the health of women. While men, women, and children all are susceptible to environmentally-related health issues, women have particular conditions which are specifically related to their gender 
(EHSO). Women's bodies are subject to menstruation, pregnancy, lactation, and menopause, all of which may influence the body's ability to respond to the toxicity of chemicals (Vahter et al. 2007, 70-84).

Consider first illnesses associated with pesticides, metals, and other substances that are introduced into the body via ingested food, inhaled air or gases, or dermal contact. Research indicates that women may be more susceptible to these illnesses as we tend to carry more fat, something about which I have personal experience (UNEP 2008). Because of this, substances may accumulate in women's bodies at higher levels than in the bodies of men.

Another gendered health concern that is associated with postmenopausal women is osteoporosis, a debilitating condition characterized by the loss of bone density. (Kanis et al. 1994, 1137-1141). Cadmium, lead, and possibly other heavy metals found in the environment may be factors in developing this disease (EHSO). Osteoporosis may, in turn, have an impact on the incidence of other diseases. Researchers are investigating the health consequences of lead that is released into the blood stream and soft tissue due to osteoporosis, one effect of which may be an increased risk of hypertension (Silbergeld et al. 1988).

Exposure to metals in the environment also may be a risk factor for genderrelated conditions that impact reproduction, bearing and nursing children, and children's health (EHSO). Further, women also greatly influence the health of their children; both pre, peri-, and post-natally. For example, prenatal exposures to mercury, lead, and arsenic, are associated with increased risk for miscarriage and for brain damage, neurodevelopmental problems, congenital malformations, and low birth weight (Harrison 2009).

Researchers are beginning to consider the role of environmental estrogens in disease processes. Environmental estrogens are a variety of synthetic chemicals and natural plant compounds that are thought to mimic the female hormone estrogen. These compounds are environmentally ubiquitous and include pesticides such as the DDT, kepone, polychlorinated biphenyls (PCBs), dietary natural plant products, and the drug DES. There are some data that suggests that these chemicals may be associated with diseases such as cancers of the breast, uterus and ovaries; endometriosis, and uterine fibroids (Calle et al. 2002).

Endometriosis is another gendered health condition for which estrogen exposure may be a risk factor. This is a painful condition that occurs when 
endometrial tissue grows outside the uterus and causes the development of painful implants on the ovaries, the fallopian tubes and the ligaments that support the uterus, the bladder, bowel, and vagina. Endometriosis affects an estimated ten to fifteen percent of premenopausal women, and environmental estrogens may contribute to the development of endometriosis in susceptible individuals (Reir \& Foster 2002).

Environmental factors also are associated with autoimmune diseases such as multiple sclerosis, rheumatoid arthritis, scleroderma, and systemic lupus erythematosus, to which research suggests women are disproportionately susceptible (Loveren 2000). For example, exposure to various chemicals in the environment, for example, hydrazine, an industrial chemical, and tartrazine, a food additive, are associated with lupus (Hess 2002). Scleroderma-like conditions also have been associated with workplace exposure to vinyl chloride and silica dust (D'Cruz 2000).

It is not only a woman's physiology that makes her more vulnerable to health issues associated with the degradation of the physical environment, but the socioeconomic environment in which she exists also may increase her susceptibility to disease. Consider for a minute a broader definition of "the environment," a definition that includes not only specific agents but also the physical and psychological areas in which women live and work. Data indicate that there is an inverse relationship between income and other socio-economic status with environmental risk factors including hazardous wastes, ambient and indoor air and noise pollutants, water quality, residential crowding, housing and neighborhood conditions, educational opportunities, work and environments (Evans \& Kantrowitz 2002). Women are disproportionately impacted by exposure to smoke from use of biomass for cooking in the home, poor access to water, and inadequate sanitation facilities; the additional time that these conditions require, i.e., water and fuel collection, have educational and income-production opportunity costs (Cutter 1995).

Violence against women also is a public health concern that is related to this broader definition of "the "environment." Socio-spatial demographics and physical environmental conditions, including a woman's level of education, financial autonomy, and level of empowerment; her partner's use of alcohol and drugs and employment status; and the degree of economic inequality between men and women, levels of female mobility and autonomy, attitudes towards gender roles and violence against women, and levels of male-male aggression and crime, all influence a woman's risk of being a victim of violence (WHO 2005). 
These are just a few examples of the many health issues that are associated with environmental factors, many of which persist in Rio's socio-physical environment and by which the Girl from Ipanema and other female residents of Rio may be uniquely impacted. As a visitor, this is both shocking and disturbing. How do Cariocas abide any threat to the precious natural environment in which they are privileged to live? Rio's amazing beauty is, in large part, attributable to its physical environment, but this splendor conceals serious environmental hazards, hazards that may have health consequences for all Cariocas and to which we were exposed during the Study Space workshop.

Threats to public health have long been a concern for Rio's city planners and citizens (Adamo 1983) and still are.

[U]rbanization has brought about combined processes of social exclusion, spatial segregation, and environmental degradation. According to data from several sources, in Brazil 26 million people living in urban areas do not have access to water; 14 million are not served by rubbish collection; 83 million are not connected to sewage systems; and 70 per cent of the collected sewage is not treated. Other figures suggest that despite the often long distances involved, 52 million Brazilians walk to work, given the high costs of public transportation. The national housing deficit has been estimated as 7.9 million units; even more alarmingly, the number of existing vacant properties has been estimated as 5.5 million units. Urban violence is increasing, especially in peripheral areas (Fernandes 2007).

Rio's rapid urbanization has increased the demand for lower-income housing. This has lead to occupation of areas unfit for habitation including areas prone to frequent flooding, steep hillsides, areas prone to dangerous erosion, and areas of environmental protection (Dalla 2008). In their continuing search for adequate housing, "Brazilians have been self-constructing a precarious, vulnerable and insecure habitat in favelas, irregular and clandestine land subdivisions, irregular housing projects, front- and-back houses, as well as by increasingly occupying public land, steep hills, preservation areas, water reservoirs and riverbanks (Fernandes 2007). These settlements, which are clearly visible in the hills and forested slopes surrounding the city and which often lack even the most rudimentary infrastructure, can have serious health and environmental consequences (Dalla 2008). The 
destruction of habitat is one example of the negative environmental consequences of such unregulated urban expansion. Surveys report that just one community alone, Alto da Boa Vista, has lost nearly $48 \%$ of its total area (Dalla 2008).

While a "Myth of Personal Security" (Arias \& Rodrigues 2006) circulates among favelados, these overcrowded mega-slums can be dangerous and violent places (Crawford 2009). Murder rates in the city of Rio are in excess of 40 per 100,000 inhabitants, and rates are much higher in some of the city's favelas (Arias \& Rodrigues 2006). From a health perspective, data suggest that this type of unregulated urban expansion can lead to the spread of disease due mainly to the lack of basic sanitation, to the poor management of solid wastes, and to the lack of drainage (Dalla 2008). Further, inhabitants live with the constant threat of landslides and the collapse of buildings (Dalla 2008).

Urbanization also has had an enormous impact on the city's waters, including both the Guanabara Bay and Sepetiba Bay. Guanabara Bay is the body of water for which Rio was named. The Bay was discovered by the Portuguese in 1502, who named it Rio de Janeiro because they mistook it for a large river flowing to the sea. It is the setting of the iconic tourist attraction, Pão de Açucar, and an impressive yacht club, but also is home to 2 harbors, 12 shipyards, a landfill, 16 oil terminals, 2 oil refineries, tens of thousands of factories (Marques Júnior et al., 2006), and Santos Dumont commuter airport. "People throw almost everything into the rivers, for instance car tires, and even aborted fetuses .... Although several sewage treatment plants have been constructed in the past 20 years, increasing the total number to six, only $15 \%$ of the enormous amount of domestic and industrial waste discharged into the bay was subjected to any form of sewage treatment in 1991 . . (Meijers et al., 2010). Further, in 2000, a catastrophic oil spill occurred in the Bay when a pipeline collapsed and pumped 1.3 million tons of oil into the water (Silva et al., 2007).

Despite the presence of biologic waste, high levels of heavy metals such as zinc, mercury, and copper, tankers, and oil refinery terminals in the Bay (Meijers et $a l ., 2010)$, it still is a stunning natural setting. However, a visit to the empty streets and beaches of the Bay's once-flourishing tourist island, Ilha Pacquetà, is a stark and very visible reminder of the economic consequences of pollution. Pollution also has serious health consequences, including the risk for diseases such as dengue and yellow fever (Meijers et al., 2010). The Bay has suffered serious damage, and local 
populations too have suffered, some of whom rely upon the Bay for food, drinking and bathing water, and income (Meijers et al., 2010).

This situation also exists in a bay in the south of state of Rio, Sepetiba Bay. Sepetiba too has suffered negative effects from human occupation and basin industrial activities, including metallurgical and petrochemical facilities and pyrometallurgical smelters (Molisani et al., 2004). Once a popular vacation spot for Brazilians, the polluted Sepetiba beaches no longer attract tourists, In addition to economic impacts, surveys have shown that residents, flora, and fauna in the area are subject to a number of environmental risk situations such as water, soil and air contamination and wasterelated problems (Ferreira A.P. 2009).

Compounding the health consequences of these sorts of environmental conditions are the socio-economic conditions to which vulnerable populations are exposed. Poor women report a lack of access to urban services, jobs, adequate housing, education, and health care (Wheeler 2003). Public health care is inadequate; public clinics and hospitals are crumbling and overcrowded and do not have the resources to provide basic care (Wheeler 2003).

Persistent conditions such as these seem almost sacrilegious and antithetical to Brazil's commitment to providing its citizens with a healthy environment. Indeed, Article 225, of the Brazilian Constitution, states that all citizens are entitled to an ecologically-balanced environment, an asset for the common use of the people, and essential toa healthy quality of life (Constitui o da Republica Federativa do Brasil [C.F.] art. 225, 1988). The Constitution also established health care as a "right of all and the duty of the state" (Constitui o da Republica Federativa do Brasil [C.F.] art. 196, 1988).

Legal mechanisms and institutions have been created to enforce these rights were created (McAllister 2008). A 1985 statute created the ação civil pública, and various changes to existing law and the passage of the 1988 Constitution clarified the mission of the Brazilian Ministério Público, a "fourth branch" of government that holds other branches of the government accountable (Crawford 2009). The Ministério Público is engaged in litigation pertaining to health, safety, and environmental protection (Crawford 2009).

In Rio, there has been a long-standing commitment, at least a superficial one, to the protection of the environment and public health. Diseases such as yellow fever, tuberculosis, malaria, and smallpox were present among the population of Rio at the 
turn of the century, attributable in part to unsanitary and overcrowded housing (Crocitti 1997). As we read during our workshop, these public health issues were considered, at least ostensibly, as part of the city's early planning process of 1902-06 as directed by Paris-trained engineer Francisco de Pereira Passos (Underwood 1992). However, many of the reforms implemented during this period of urban improvement only shifted the public health issues to the city's periphery as many of the working class and poor living in the city were forced into crowded conditions in the remaining tenements or into the favelas (Boone 1995).

There were other reforms attempted during this era of Rio's history. Dr. Oswaldo Cruz, after whom the highly-regarded Oswaldo Cru Foundation is named, instituted a mandatory smallpox vaccination campaign and a plan to drain the pools of water in which yellow fever-carrying mosquito bred (Boone 1995). While Dr. Cruz's campaign as successful in eliminating yellow fever and plague, riots forced the government to suspend the mandatory vaccination campaign (Boone 1995).

Despite such early failures, city officials still are seeking solutions to environmentally-related health concerns. Rio's rapid urbanization has created the classic moral dilemma for city officials and residents: which issues take precedence, the housing crisis or the protection of public health and the environment? The challenge for planners is to integrate health and environmental protection into urban and housing planning (Dalla 2008). And it is clear that the threat to the Girl from Ipanema and her sisters and brothers is being taken seriously by national and municipal leaders. Issues of social and spatial inclusion, socio-environmental sustainability, and the health affects thereof have entered the public discourse and into the legal demesne. For example, Brazil enacted Federal Law no. 10.257, the 'City Statute', which explicitly recognizes the 'right to the city' (Fernandes 2007). This 2001 federal law provides a legal foundation to those municipalities seeking to respond to "the grave urban, social and environmental problems that have directly affected the daily living conditions of the urban population" (Fernandes 2007).

One example of one such response is the ambitious Programa de Despoluicao da Baia de Guanabara. The Brazilian federal and Rio State governments commenced this program in the 1990's to improve environmental quality in the Guanabara Bay region, with a focus on the construction of a sewage and wastewater treatment facilities (Banco Interamericanode Desenvolvimeto 2006). 
Brazil also is tackling socio-environmental factors that pose health risks to the Girl from Ipanema. Gains have been made in access to health care for women. The Comprehensive Program for Women's Healthcare provides maternal care and family planning, breast and cervical cancer screening, diagnosis and treatment of STDs, and infertility services (Rahman 1995). Brazil also has enacted legislation which criminalizes domestic violence (Lei No. 11.340, de 7 de agosto de 2006). The law was inspired by a victim of intimate violence, María da Penha Maia Fernandes, who resorted to the Inter-American Commission on Human Rights ("Commission") for protection from her abusive husband (Inter-Am. C.H.R., Report No. 54/01, OEA/Ser.L./V/II.111, doc. 20 2001). In the case, the Commission determined that the Brazilian government's fifteen-year failure to prosecute Mrs. Fernandes' attempted murder by her husband following the filing of criminal charges constituted genderbased discrimination and reflected a "general pattern of negligence and lack of effective action by the State in prosecuting and convicting aggressors" that created a "climate that is conducive to domestic violence[ ]" (Inter-Am. C.H.R., Report No. 54/01, OEA/Ser.L./V/II.111, doc. 20 2001).

There are other socio-economic factors that have negative health consequences to which the federal and state governments are attending. While controversial, Rio's choque de ordem campaign ostensibly has been implemented to clean the city of waste and violence. Rio also is moving to "regularize" its informal settlements and favelas. Its Favela Bairro program seeks to transform these settlements into formal neighborhoods with an emphasis on infrastructural and living condition improvement (Handzic 2010). Women's issues also are likely to receive increased political attention as more women enter politics at the local level, including women of color and women from the ranks of the poor and working classes.

To conclude, now is a historic moment for Rio de Janeiro. The city will host both the 2014 FIFA World Cup and the 2016 Summer Olympic Games. It is justifiably proud of its success in attracting these events and is entitled to celebrate about the anticipated economic benefits that these events will generate. However, Cariocas must not forget that event tourists also will expect to meet the beautiful Girl from Ipanema when they visit. Accordingly, as the city prepares for these mega-events and implements the many improvement projects that such events require, it should strive to create a healthy physical and living environment for the Girl and her sisters and 
brothers of which all can be proud. Rio has an opportunity to take advantage of this momentous confluence of events to ensure that women and the poor are able to fully participate in the city's celebrations, and it must take care that these vulnerable groups are not once again excluded from, or the victims of, the city's success.

\section{REFERENCES}

Abbott, F.M. 2002. The Doha Declaration on the TRIPS Agreement and Public Health: Lighting a Dark Corner at the WTO. J. Int. Economic Law 5 (2).

Adamo, S.C. 1983. The Broken Promise: Race, Health and Justice in Rio de Janeiro, 1890- 1940. Ph.D. Dissertation. The University of New Mexico.

Arias, E.D., and C.D. Rodrigues. 2006. The Myth of Personal Security: Criminal Gangs, Dispute Resolution, and Identity in Rio de Janeiro's Favelas. Latin American Politics and Society. 48 (4): 53-81.

Boone C. G. 1995. Streetcars and Politics in Rio de Janeiro: Private Enterprise versus Municipal Government in the Provision of Mass Transit, 1903-1920. Journal of Latin American Studies. 27 (2): 343-365.

Calle E.E.; H. Frumkin, S.J. Henley, D.A. Savitz, M.J. Thun. 2002. Organochlorines and Breast Cancer Risk. CA Cancer J Clin. 52(5): 301-9. Review.

Constituição da Republica Federativa do Brasil 1988[C.F.] art. 196.

Constituição da Republica Federativa do Brasil. 1988 [C.F.] art. 225.

Crawford C. 2009. Our Bandit Future? Cities, Shantytowns, and Climate Change Governance. Fordham Urb. L.J. (36): 211-252. 
Crocitti, J. 1997. Social Policy as a Guide to Economic Consciousness: Villas Operárias in Rio de Janeiro, 1890- 1910. Luso-Brazilian Review. 34 (1): 1-15.

Cutter, S.L. 1995. The Forgotten Casualties: Women, Children, and Environmental Change. Global Environmental Change 5 (3) (June): 181-194.

Dalla Bernardina de Pinho, H. 2008. The Role of Public Prosecutions in Protecting the Environment under Brazilian Law: The Case of "Favelas" in the City of Rio de Janeiro. Georgia State Univ. Law Rev. 24: 735.

D'Cruz, D. 2000. Autoimmune Diseases Associated with Drugs, Chemicals and Environmental Factors. Toxicology Letters 112-113: 421-432.

Environment, Health and Safety Online. http://www.ehso.com/ehshome/womenshealth2.htm

Evans, G.W., E. Kantrowitz. 2002. Socioeconomic Status and Health: The Potential Role of Environmental Risk Exposure. Annual Review of Public Health 23: 303-331.

Fagan T.F., D.L. Faustman. Sex Differences in Autoimmunity. In: Bittar E., (eds.). 2004. Advances in Molecular and Cell Biology. 34 Principles of Sex-based Differences in Physiology.

Ferreira A.P. 2009. Evidence of Social and Environmental Vulnerability in Sepetiba Bay: An Analysis of Risk Situations 22 (4).

Fernandes E. 2007. Constructing the 'Right to the City' in Brazil. Social Legal Studies 16: 201-208.

Handzic K. 2010. Is Legalized Land Tenure Necessary in Slum Upgrading? Learning from Rio's Land Tenure Policies in the Favela Bairro Program. Habitat International 34 (1): 11-17.

Harrison E, Partelow J, Grason H. 2009. Environmental Toxicants and Maternal and Child Health: An Emerging Public Health Challenge. Baltimore, MD. Women's and Children's Health Policy Center. Johns Hopkins Bloomberg School Public Health.

Hess E.V. 2002. Environmental Chemicals and Autoimmune Disease: Cause and Effect. Toxicology. 181-182: 65-70.

Hippocrates. 400 B.C.E. Airs, Waters, and Places. (Loeb ed.).

International Covenant on Economic, Social and Cultural Rights (ICESCR), art. 12, Dec. 16, 1966, 993 U.N.T.S. 3, 5. 
Kanis, J. A., L. J. Melton, C. Christiansen, C. C. Johnston, and N. Khaltaev. 1994. The diagnosis of osteoporosis. Journal of Bone and Mineral Research, 9: 1137-1141.

Kuszler, P.C. 2007. Global Health and the Human Rights Imperative. Asian Journal of WTO \& International Health Law and Policy 2: 99.

Lei No. 11.340. de 7 de agosto de 2006. D.O.U. de 8.08.2006.

Loveren, H. van; Vos, J.G.; Germolec, D.; Simeonova, P.P.; Eijkemanns, G. 2000. Report of the Exploratory Meeting regarding Epidemiology of Occupational and Environmental Factors Associated with Autoimmunity. RIVM Rapport.

María da Penha Maia Fernandes v. Brazil. 2001. Case 12.051, Inter-Am. C.H.R., Report No. 54/01, OEA/Ser.L./V/II.111, doc. 20.

Marques Júnior A.N.; M.A.C. Crapez, C.D.N.B Barboza. 2006. Impact of the Icaraí Sewage Outfall in Guanabara Bay, Brazil. Brazilian Archives of Biology and Tech.: An Int'l Journal. 49 (4): 643-650.

McAllister L. K. 2008. Revisiting a 'Promising Institution: Public Law Litigation in the Civil Law World. Georgia State University Law Review. 24: 693-734.

McCally M. (ed.) 2002. Life Support: The Environment and Human Health. Cambridge 1 MA: MIT Press.

Molisani, M.M., R.V. Marins, W. Machado, H.H.M. Paraquetti, E.D. Bidone, L.D. Lacerda. 2004. Environmental Changes in Sepetiba Bay, SE Brazil. Regional Environmental Change 4 (1): 17-27.

United Nations Millennium Declaration, 2000. G.A. Res. A/55/L.2.

Rahman A. 1995. Toward Government Accountability for Women's Reproductive Rights. St. John's L. Rev. 69: 203-215.

Rier S. \& W.G Foster. 2002. Environmental dioxins and endometriosis. Toxicol. Sci. 70 .

Sarkar, B. (ed.). 2002. Heavy Metals in the Environment.

Silbergeld, E.K.; J. Schwartz, K. Mahaffey. 1988. Lead and osteoporosis: Mobilization of lead from bone in postmenopausal women. Environmental Research. 47: 1.

Silva, T.F.; D.A. Azevedo, F.R. Aquino Neto. 2007. Distribution of Polycyclic Aromatic Hydrocarbons in Surface Sediments and Waters from Guanabara Bay, Rio de Janeiro, Brazil. J. Braz. Chem. Soc. 18 (3). 
Underwood, D. 1992. Civilizing Rio de Janeiro: Four Centuries of Conquest through Architecture. Art Journal. 51 (4).: 48-56.

United Nations Environment Programme. 2008. Module 1: Introduction to Chemicals Management - Most Frequently Used Chemicals: Are Some Chemicals Better or Safer Than Others? http://www.unep.org/labour_environment/PDFs/training/CHEM-M1-EN.pdf

Vahter, M.; M. Gochfeld, B. Casati, M. Thiruchelvam, A. Falk-Filippson, R. Kavlock, E. Marafante, D. Cory-Slechta. 2007. Implications of Gender Differences for Human Health Risk Assessment and Toxicology. Environmental Research, $104(1)$.

World Health Organization. 2010. 10 Facts on Preventing Disease Through Healthy Environments.

http://www.who.int/features/factfiles/environmental_health/en/index.html

World Health Organization, 2005.WHO Multi-Country Study on Women's Health and Domestic Violence against Women: Summary Report of Initial Results on Prevalence, Health Outcomes and Women's Responses. Geneva.

Woodruff T.J., and A. Carlson, J.M. Schwartz, L.C Giudice. 2008. Proceedings of the Summit on Environmental Challenges to Reproductive Health and Fertility. 89 (2). 